\title{
Sericulture: Agro-Based Industry For Sustainable Socio- Economic Development: A Review
}

\author{
Brian Ssemugenze, Joseph Esimu, Janet Nagasha, Clet Wandui Masiga \\ Tropical Institute of Development Innovations \\ P.O. Box, 397, Mukono -Uganda \\ DOI: 10.29322/IJSRP.11.09.2021.p11756 \\ http://dx.doi.org/10.29322/IJSRP.11.09.2021.p11756
}

\begin{abstract}
Silkworm is an important primary productive insect species reared and exploited globally to boost the sericulture industry. Sericulture industry has uplifted the social and economic livelihoods of people across the world by boosting textile industry which is key in plummeting unemployment in developing countries. Livelihood and social improvement achieved through employment opportunities, income generation, economic development, ecological and environmental values, agriculture integration and environment protection. Sericulture directly employs people in mulberry production, leaf and root harvesting, egg production, silk worm rearing, post cocoon handling technologies such as cocoon harvesting and drying, silk reeling, winding, doubling, twisting, warping, weaving, printing and designing, finishing and silk waste processing but also indirectly as traders of silk products, construction of grainage, rearing, ware and post cocoon handling houses, mechanics/operators of silk processing machinery, marketeers of the final products. Sericulture requires minimum investment, simple technology, short gestation period, increased employment opportunities with a high remunerative return fitting the agrarian economy. The industry suits all categories of people ranging from resource poor farmers, landless, children, elderly, youth, male and female and socially under privileged people. This review discusses the socioeconomic contributions of sericulture industry as a present and future viable investment for sustainable socio-economic development.
\end{abstract}

Index Terms- Sericulture, Mulberry, Silkworm, Socio-economic Development, Investment

\section{INTRODUCTION}

$\mathrm{S}$ ericulture is an agro-based industry that mainly focuses at rearing of silkworms with the main objective of silk production. Natural silk fiber is the main product of silk production obtained from domesticated silkworms (Bombyx mori) (Singh et al., 2000). Sericulture industry is described by a series of activities or stages ranging from mulberry production used to feed silkworms to silk processing activities namely weaving, dying and marketing ready silk products. Sericulture is a vast industry covering different sectors of agriculture, art and design, research and innovations, textiles. Rural and resource poor farmers value sericulture as an agricultural entity through mulberry production whereas it is also looked at as a financial investment by different stakeholders. In a situation whereby most of the farmers have constrained production resources such as land and capital to invest in agriculture, sericulture seems to answer most questions posed due to being a multipurpose agro-based industrial sector that covers all categories of people around the globe. Silk cocoon production is valued as the main product of sericulture that boosts farmers' income, acts as a raw material for silk industries. Apart from cocoons as the primary product of silk production, there are a lot of valuable secondary products for example silkworm proteins, moths and wastes which can be processed to meet different purposes such as animal feeds. Through investing in Sericulture almost thirty (30) million families across the globe (Kim et al., 2010).

Modern economies of different states across the globe have entirely benefited from the sericulture industry through the ecological, economic and social uplift. Silk production boosts farmers' income (JAICAF report, 2007), Mulberry plants used as feed for silkworms and environmental conservation (Gamble, 2011), employment opportunities (Benchamin and Jolly, 1987), social and religious benefit, subsidiary or main occupation. Silk industry faces a number of challenges namely mono cropping pattern of mulberry, poor quality silkworm breeds, poor infrastructure, poorly managed mulberry plantations, shortage of silkworm rearing space, shortage of enough start-up tools for farmers and low adoption of improved technologies. There is a need to provide solutions to above mentioned challenges through infrastructure developments, awareness and training programmes to stakeholders, productivity of improved silkworm breeds in order to boost mulberry leaf production, cocoon production and post-cocoon management (Bhat, 2014). Recent studies have indicated that approximately 10 million people rear silkworm, half million people engage in silk industry, Asia is world's number one silk producing continent boosting the biggest global output (95\%), 58 countries around the world engage in silk production with China, India, Japan, Brazil and Korea as leading producers (Nagaraju, 2008). Although different studies have been conducted on the utilization of silk by-products in different countries, most of the silk secondary products such as silkworm proteins (sericin, pupae), moths and waste are not processed further causing losses to the industry. In order to enhance profit maximization of the silk industry, more purposeful and focused research should be done on the utilization of secondary wastes (Majumder, 1997).

Sericulture industry being a cottage, agro and forestry based industry has been seen to enhance sustainable livelihood of rural communities in different countries, socio-cultural and traditional linkages, enhanced rural economies and other so many attributes 
as shown below (figure i). With all the above mentioned attributes of the silk industry, it is appropriate to call sericulture an ideal industry for a sustainable future. Through this review paper, all the social and economic contributions of sericulture industry were put together and discussed for consideration as a present and future viable investment for sustainable socio-economic development.

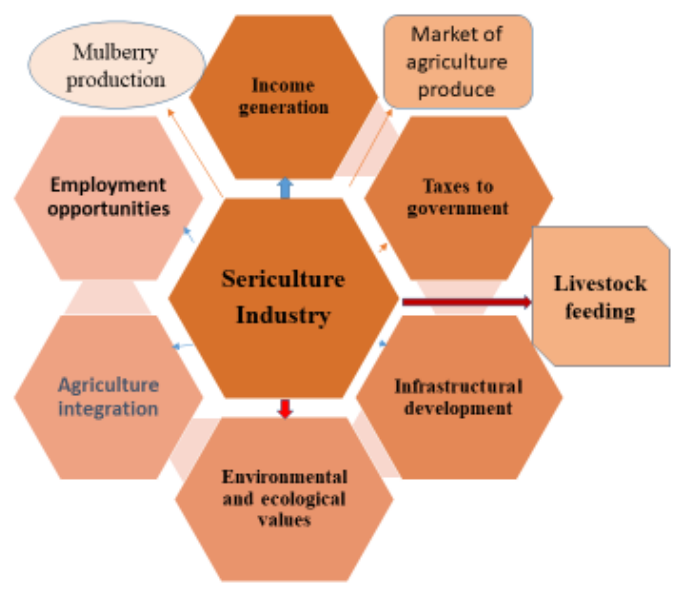

Fig $i$ : Sericulture a versatile investment industry

\section{CURRENT STATUS OF SERICULTURE IN UGANDA}

Sericultural industry has played a vital role in improving economic development in several countries across the world, Uganda inclusive. Main Silk producing countries in the world are ranked in the order below: China, India, Uzbekistan, Brazil, Japan, Republic of Korea, Thailand, Vietnam, DPR Korea, and Iran but a few others that produce minute quantities are recognized; Kenya, Botswana, Nigeria, Zambia, Zimbabwe, Bangladesh, Colombia, Egypt, Japan, Nepal, Bulgaria, Turkey, Uganda, Malaysia,
Romania, Bolivia (International Sericultural Commission, 2018). In their annual project report, Tropical Institute of Development Innovations reported that sericulture and mulberry cultivation has so far covered over 50 Districts in Uganda namely: Mubende, Busia, Zombo, Bulambuli, Bukedea, Pallisa, Kiruhura, Mbarara, Nwoya, Sheema, Luweero, Nakasongola, Buikwe, Gomba among others (Figure ii and Table 1) (Commercialization of Sericulture Technologies and Innovations in Uganda project report 2020, Tropical Institute of Development Innovations). According to the International Sericultural Commission Statistics, 2020, Uganda was ranked $20^{\text {th }}$ out of 22 silk producing countries with 3.10 metric tonnes of silk produced in the year 2019.

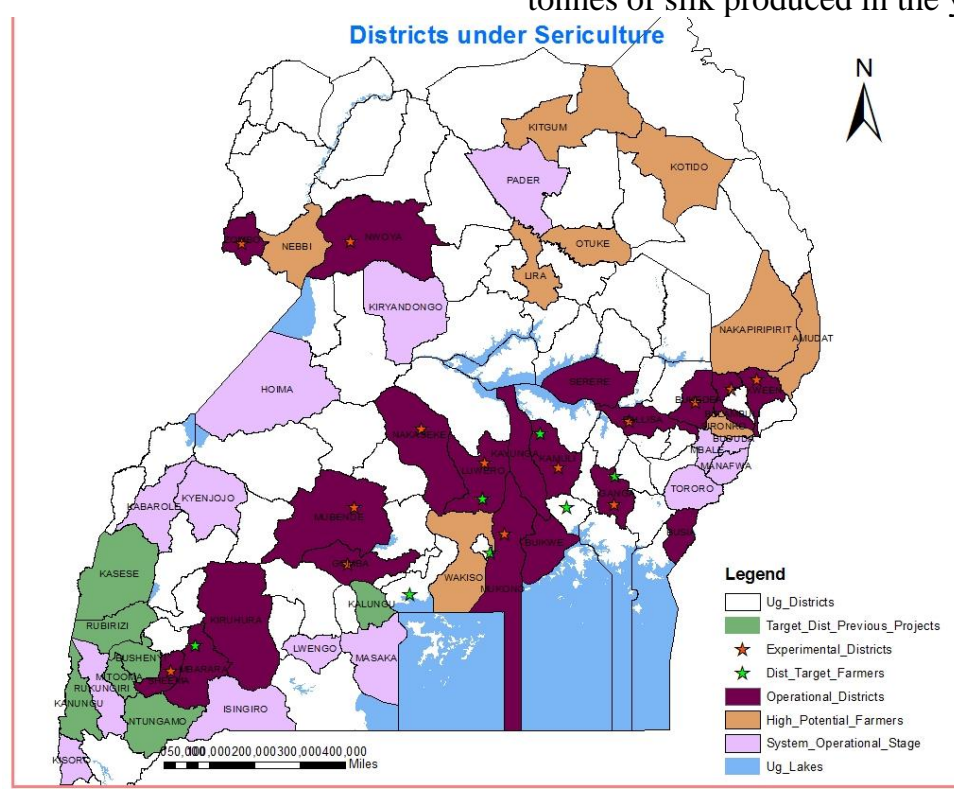

Fig ii: Map showing districts under sericulture and Mulberry production in Uganda (Generated by Sarah Babirye, TRIDI) 
Table 1: District-wise cocoon production in Uganda

\begin{tabular}{|l|l|l|}
\hline No. & District & $\begin{array}{l}\text { Cocoon production per box of } \\
\text { silkworm eggs (Kgs) }\end{array}$ \\
\hline 1. & Sheema & 26.5 \\
\hline 2. & Namasumbi (Mukono) & 29.2 \\
\hline 3. & Iganga & 22.7 \\
\hline 4. & Kamuli & 29.2 \\
\hline 5. & Tom (Kamuli) & 26.3 \\
\hline 6. & Anthony (Palisa) & 25.5 \\
\hline 7. & Angule (Palisa) & 23.8 \\
\hline 8. & Kayunga & 28.6 \\
\hline 9. & Bulambuli & 27.5 \\
\hline
\end{tabular}

Source: (Commercialization of Sericulture Technologies and Innovations in Uganda project report 2020, Tropical Institute of Development Innovations)

\section{EMPLOYMENT OPPORTUNITIES}

Both rural and urban communities have benefited from sericulture industry through direct and indirect employment engaging in a series of valuable activities to include mulberry production and cultivation, silkworm rearing, silkworm seed production, silk cocoon reeling, silk fabric making, printing, dyeing as well as marketing silk products. Globally unemployment rate stands at $5.42 \%$ in 2021 compared to $5.4 \%$ in $2019,60 \%$ of global population depends on agriculture for survival, 1.1 billion engaging in agriculture with 300-500 million waged workers. Agriculture is expected to feed 9.7 billion people by 2050 hence need to uplift the sector through diversification (International Labour Organization, ILOSTAT database, 2021). Globally, it was estimated by Kim et al., 2010 that more than 30 million families are employed in the Silk Industry. China employs about 1 million people in silk industry, 7.9 million people in India, and 20,000 weaving families in Thailand. Tasar sericulture being one of the main types of sericulture practised in different states of India employs a total of 11 people per kilogram of raw silk produced and 0.38 lakh weavers (Ramalaxmi, 2007; Suryanarayana and Shrivastava, 2005). Sericulture employment opportunity trends: 38.06 lakh of people employed during the year 1977-78 (Hanumappa, 1993), 68.17 lakh people employed during 2009-10 (Ganie et al., 2012), 72.5 lakh people employed by 201011 with 52.20 lakh (farmers), 3.70 lakh (reelers) and 16.60 lakh (weavers). Jammu and Kashmir state of India has a total of 3741 handloom units which employ people producing loies, puttos, tweed, blankets, raffals, pashmina and dusotikhad (Bhat et al., 2019). Silk industry in Kashmir across produced 800 MT of cocoons with an employment rate of four lakh man-days annually, 22, 000 sericulture farmers employed by the industry (Bilal, 2010). 


\section{INCOME GENERATION}

Sericulture and silk production serve as a source of income to resource poor farmers (Singh and Andrabi, 2019). Silk industry contributes to socio-cultural and traditional linkages in India through livelihood improvement (Mahapatra, 2009). Currently in Uganda, one of the leading research institution promoting sericulture production (Tropical Institute of Development Innovations) under the project entitled 'Commercialization of Sericulture Technologies and Innovations in Uganda' implemented in more than 26 districts, a total of 65 technical staff are employed, around 100 casual labourers are employed directly employed in Mulberry plantations, all these employees earn a living in form of salaries and wages from sericulture related activities.

\section{ECOLOGICAL AND ENVIRONMENTAL VALUES}

Natural resources utilization and socioeconomic uplift of rural farmers through livelihood improvement by providing employment opportunities and income generation (Lalhmingsangi, 2019). Sericulture realizes environment values: land ecorestoration and bioremediation, air purification, carbon sequestration and conservation of soil and water attributed mainly to mulberry production (Huang and Wang, 2012; Qin et al., 2012). Water and soil conservation by Mulberry plants (Du et al., 2001). Mulberry afforestation restored: soil carbon, improved soil water holding capacity, soil erosion control, nutrient recycling, maintenance of soil micro flora (Zhang et al., 1997; Lin et al., 2008). Mulberry plant extracts traditionally used in Indian ayurvedic system of medicine to treat different health ailments thus improving human health (Ghosh et al., 2017). Silk protein acts as: human food and as Control Ecological Life Support (CELIS) in the world (Dandin and Kumar, 2007)

\section{AGRICULTURE INTEGRATION}

Agriculture diversification has proved beneficial to farmers as they can't suffer total losses in case one of the enterprises fails due to both abiotic and biotic stresses. Mulberry plantation allows intercropping with grass which can be used as animal feed, vegetables for food and other cash crops for generating income (Shi et al., 2005; Qin et al., 2012). Intercropping Mulberry had a good number of benefits: soil fertility improvement (Farrar, 1995), soil and water conservation (Shi et al., 2005), environmental sustainability (Hashemi and Tabibian, 2018; Dai et al., 2009), boosting economy (Datta, 2000).

\section{INFRASTRUCTURAL DEVELOPMENT}

Government silk factories, silk reeling units improved rural and infrastructure in Jammu division (Afifa, 2000). Uniform infrastructure development and benefits through different ambitious flagship programmes which enriched the economy and narrow down the rural-urban gap (Farhat et al., 2010). Development of silken carpet from reeled mulberry silk by the Indian Institute of Carpet Technology (IICT) through the area of Research and Development (Kaneez, 2018). Organization of silk and cocoon auction market, sericulture exhibitions by sericulture authorities where growers sold their cocoons to local and outside merchants (Ganie et al., 2018).

\section{WOMEN EMPOWERMENT}

Sericulture is an effective source of employment and income generation to women all over the globe as they engage in various activities right from egg production to weaving since this venture is seen as remunerative employment for family members and economic benefit to farming households. Studies have indicated that women engage in hands-on operations in a number of agriculture activities (Prasad \& Chandra, 1991). In India, 53.4580 percent of women engage in sericultural activities but this is more dependent upon the type of activity (Bukhari et al., 2019). A good number of workers in the silk industry are the vulnerable group women inclusive (Best \& Maier, 2007; Bhatta \& Rao, 2003; Geetha \& Indira, 2011). Women contribute at almost all stages of silk production such as Mulberry production for silkworm feeding, indoor rearing of silkworm (Bhat et al., 2019). Bhat et al. (2019) compared the gender involvement in sericulture and established the contribution of both male and female labour force. A total number of 8 million people in both rural and semi-urban areas in India are employed in the Sericulture industry with over $60 \%$ of the workforce being women, $80 \%$ of the silk produced is consumed by women. Women constitute over $60 \%$ of those employed in down-stream activities of sericulture in the country (Kritika Sharma, 2020). Though, women are employed in Sericulture and earn a living but face challenges as highlighted by Bukhari et al., 2019, lack education qualification therefore need for capacity building through effective sensitization trainings as this will ensure economic development through women empowerment in form of employment in rural communities.

\section{ANIMAL/LIVESTOCK FEEDING}

Sericulture industry has helped boost livestock production by improving the feeds sector. This has been achieved in two different ways namely feeding Mulberry leaves to animals and processing of silkworm secondary products like pupae to make livestock feeds. Mulberry leaves being easily digestible and palatable, fed as supplement to boost milk production from dairy animals. Milk protein, lipid and carbohydrate content enhanced in cows and goats due to feeding mulberry (Venkatesh et al., 2015), milk yield and fat content of cow milk increased due to mulberry feeding (Datta et al. (2002). As well as direct benefits are observed, various economic benefits such as feeding cost reduction was achieved when mulberry leaves were used as a substitute feed to feed small ruminants such as pigs and rabbits (Sanchez, 2002).

\section{MULBERRY PRODUCTION}

One of the major activities of sericulture is Mulberry production which is practised by farmers and companies, initially it was intended to feeding silkworm but the crop has proved to be multipurpose thus making it an ideal crop for both resource poor and commercial farmers around the world. Different researchers have documented the importance of Mulberry as shown below (Fig. iii): medicinal plant which improves and enhances human life due a variety of important biological ingredients contained. Mulberry has a variety of applications namely: Pharmaceuticals, food industry and cosmetic industry, treatment of rheumatis and arthritis by traditional ayurvedic practitioners. (Yang et al., 2010a; Zhang et al., 2018). Used as treatment for diabetes medicine due 
to its antidiabetic molecules like 1-deoxynojirmycin, isobavachalcone, morachalcon, fagomine, quercetin (Wang et al., 2013; Kiran et al., 2019). Treat of hypertension, hyperglycemia, inflammation, fever, cough and cancer in China, (Bown, 1995). Control of blood pressure in China when the young shoot and leaf tips were taken as tea, anthocyanin content and antioxidant (Datta, 2000; Qin et al., 2012), human health promotion (Del et al., 2013), animal feeding and environment protection (Datta et al., 2002). Recreational purposes and soil erosion control measures cultivated along the road sides, river banks, flood plains, public parks, gardens, edges of field crops, street trees (Qin et al., 2012). Singh (1997) revealed that mulberry fruit syrups and recipes are used against constipation and insomnia, anti-aging, hyperlipidemia, premonitory and apoplexy.

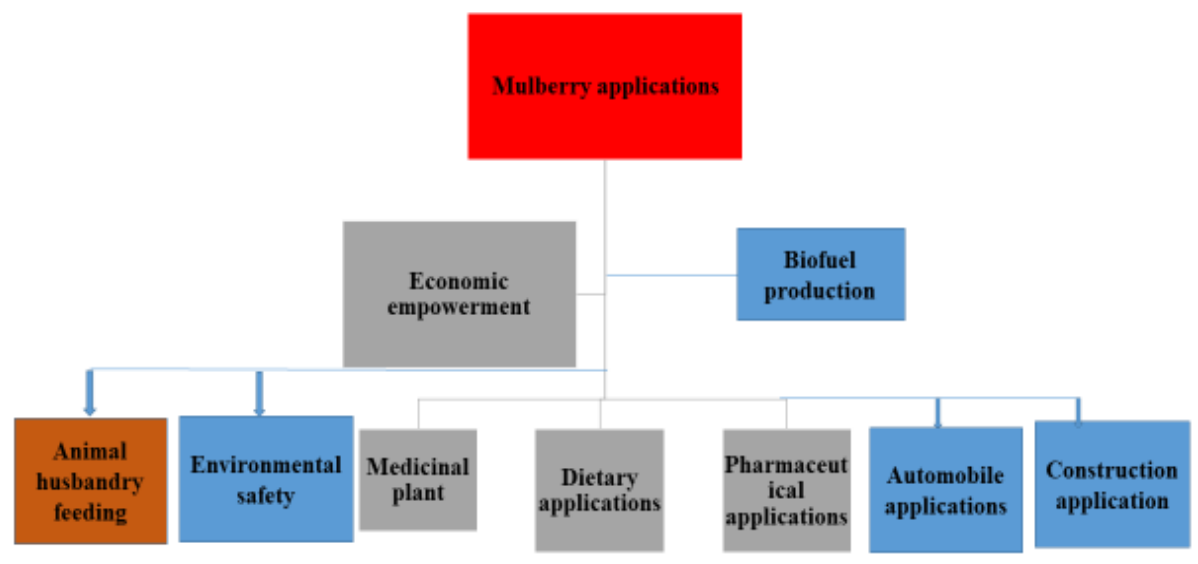

Fig. iii. Applications of mulberry plant

\section{FOREIGN EXCHANGE}

Sericulture is seen as an investment agro-based industry by most of the countries that generates foreign revenue through different exports and imports, foreign exchange earner for rural communities in India (Thapa and Shrestha, 1999), A total of 25000 oz of silkworm seeds supplied to Europe from Kashmir gaining strong position on the silk route of Europe (Baqual, 1995). According to a market survey done in India, an income of USD 1063.72 - 1161.70 was generated from sale of mulberry jam and pulp in markets across the country (Singhal et al., 2009ab).

Table 2: Silkworm products and their applications

\begin{tabular}{|l|l|l|l|}
\hline No. & Products and waste products & Application & Reference \\
\hline 1. & Silk sericin & $\begin{array}{l}\text { Oxidation resistance } \\
\text { UV rays resistance }\end{array}$ & $\begin{array}{l}\text { Gulrajani, 2006 } \\
\text { Senhal, 2008 }\end{array}$ \\
\hline 2. & Silk biopolymer & $\begin{array}{l}\text { Tissue regeneration } \\
\text { Wound healing }\end{array}$ & $\begin{array}{l}\text { Kumaresan } \text { et al., 2007 } \\
\text { Federico } \text { et al., 2007 }\end{array}$ \\
\hline 3. & Silk fibroin peptides & Cosmetic making & $\begin{array}{l}\text { Kumaresan } \text { et al., 2007 } \\
\text { Federico } \text { et al., 2007 }\end{array}$ \\
\hline 4. & Silk proteins & $\begin{array}{l}\text { Speciality diet for cardiac and } \\
\text { diabetic patients }\end{array}$ & $\begin{array}{l}\text { Ramesh } \text { et al., 2005 } \\
\text { Reddy, 2008 }\end{array}$ \\
\hline 5. & Dried cocoon palade powder & Poultry and fish feed & Iyengar, 2002 \\
\hline 6. & $\begin{array}{l}\text { Serratio peptidate (Serrapeptase intestinal } \\
\text { enzyme) }\end{array}$ & $\begin{array}{l}\text { Anti-inflammatory } \\
\text { Anti-tumefacient } \\
\text { Enhance blood circulation } \\
\text { Treat arterial plaque }\end{array}$ & $\begin{array}{l}\text { Reddy, 2008 } \\
\text { Feng, 2004 }\end{array}$ \\
\hline 7. & Silk fibroin & $\begin{array}{l}\text { Dressing material } \\
\text { Veterinary medication }\end{array}$ & $\begin{array}{l}\text { Gulrajani, 2006 } \\
\text { Kumaresan } \text { et al., 2007 } \\
\text { Sehnal, 2008 }\end{array}$ \\
\hline 8. & Silk fibre & $\begin{array}{l}\text { Surgical sutures } \\
\text { Teeth reconstruction }\end{array}$ & $\begin{array}{l}\text { Gulrajani, 2006 } \\
\text { Wang } \text { et al., 2006 }\end{array}$ \\
\hline 9. & Silk fibroin nerve guidance conduit & $\begin{array}{l}\text { Peripheral nerve regeneration } \\
\text { Collagenisation }\end{array}$ & Yan et al., 2009 \\
\hline
\end{tabular}




\begin{tabular}{|l|l|l|l|}
\hline 10. & Silk fibre and polypropylene & House construction & $\begin{array}{l}\text { Shigetaka and Teruo, 2002 } \\
\text { Zultifli } \text { et al., 2008 }\end{array}$ \\
\hline 11. & Silk based paper & Art craft & Reddy et al., 2008 \\
\hline 12. & Silkworm pupae and excreta & $\begin{array}{l}\text { Animal/poultry feed } \\
\text { Silkworm pupal cakes } \\
\text { Medicinal wine } \\
\text { Treat osteoarthritis } \\
\text { Preparing amino acids and } \\
\text { flavoured products }\end{array}$ & $\begin{array}{l}\text { Qadri } \text { et al., 2015 } \\
\text { Datta } \text { et al., 2007 }\end{array}$ \\
\hline 13. & Silkworm powder & Lowering blood-glucose levels. & Ryu et al., 1997 \\
\hline 14. & Silkworm extract & $\begin{array}{l}\text { Treat prostate hyperplasia and } \\
\text { erectile } \\
\text { dysfunction }\end{array}$ & Qian, 1997 \\
\hline 15. & silkworm moth oil & $\begin{array}{l}\text { Textile dyes } \\
\text { Superior soaps }\end{array}$ & Gui and Zhuang, 2000 \\
\hline 16. & Silkworm Litter & Organic manure Biogas & Sharma and Madan, 1992 \\
\hline
\end{tabular}

\section{SILKWORM SECONDARY PRODUCTS AND THEIR APPLICATIONS}

The primary product obtained from silkworm is the silk fiber used as a raw material for the textile and silk fabric industry to manufacture silk garments like shirts, sweaters, clothes as well as weaving. On top of the primary goal of attaining silk, what makes sericulture a more viable venture are the secondary products that serve different purposes which are medicinal, human food, animal feeds and so many others. Many researchers have documented the importance of these secondary products but much attention has been drawn to silk pupae, litter, sericin and fibroin (Figure iv, Table 2).

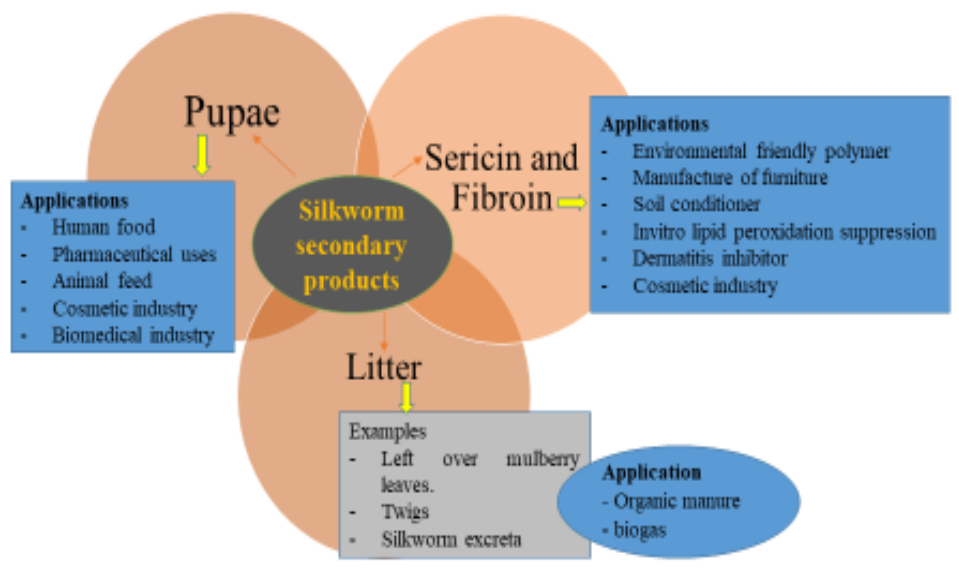

Fig. iv: Silkworm secondary products and their applications

\section{SILKWORM PUPAE}

Pupa is composed of crude proteins, fats, amino acids, sugars, phosphorous, vitamins, calcium in different concentrations, if eaten by human beings and livestock dried silkworm pupae provides daily protein need (Singh and
Suryanarayana, 2003). The nutritive value of pupae is attached to its composition: vitamins (pyridoxal, riboflavin, thiamine, ascorbic acid, folic acid nicotinic acid, pantothenic acid) and minerals namely calcium, iron copper, selenium and phosphorus making it a better feed for lactating mothers (Koundinya and 
Thangavaleu, 2005; Singh and Suryanarayana, 2003). Silkworm pupae is an industrial raw material used to make different products to include: chrysalis oil for cosmetics, fertilizer and animal feeds for poultry, pigs, fish and fur bearer animals, pupal oil used by the pharmaceutical industry due to its anti-inflammatory, antitumefying properties to treat sinusitis, otitis, bronchitis, asthma, tuberculosis, urinary infections and after surgery operations.

Pupae used in the food industry due to valuable characteristics it possesses like refractive index, safonification value, iodine value and cholesterol content (Choudhury, 2003), raw material in preparation important amino acids and flavoured products having high nutritive value (Aruga, 1994). Crunchy chitin and Pectin which form the exoskeleton of silkworm pupae act as supplements for the cereal diet, making pupae chocolates, Japan cakes and chilli sauce, increasing loaf volume of wheat flour bread, making candy, wine, jelly, jam, fruit juices and ice creams (Roy choudhury and Joshi, 1995; Majumder, 1997; Ramakanth and Raman, 1997). In Africa, silkworm pupae have various applications like dried and powdered Saturniids used as a garnish and consumed by human beings.

Silkworm pupae is used in bio-medical industry as reported by different researchers: Chitin is used in post operational treatments to include conchotomy, deviatory, polypectomy due to its ability to cause less hemophase, relieves pain and speeds up wound healing. It is also used as useful anti-microbial agent against Staphylococcus aureus, Klebsiella pneumoniae, Asppergillus nige and anti-fungal against Trichophyton equinum. Plays important biomedical roles of preventing carcinogenic bacteria from teeth and biocompatible membrane due to different properties such antiviral agent, bacteriostatic, fungistatic, antisordes (Katti et al., 1996). Dried silkworm pupal animal feed was used to promote poultry growth, improve egg quality, feed use and specific growth rate in fish, increased weight gain and growth rate of rabbits and fur (Velayudhan et al., 2008).

\section{SILKWORM LITTER}

The term 'ploughing back' is commonly used to mean taking back plant remains back to the garden in order to enhance soil fertility as well as improve soil conditions. This is the same case with sericulture industry whereby silkworm litter mainly are drawn back to the farming community in form of organic fertilizers. Excreta act as an organic fertilizer due to its composition of water, crude protein, raw fats, raw cellulose, substances without nitrogen but can also as a chlorophyll source using alcohol extraction method (Buhoro et al., 2018).

\section{SILKWORM SERICINE AND FIBROIN}

Due to technological developments silkworm acts as biofactory raw material for producing useful protein by use of the silk gland. The two promising main proteins of silkworm are sericine and fibroin mainly used in form of bandages for wound healing. But also help to treat diabetes, impotence, sinusitis, arthritis, oedema, cystitis, epididymitis, tissue regeneration, cancer, postsurgical trauma. Other benefits include: anti-oxidative, bioadhesives, ultra-violet screens, anti-wrinkle, anti-aging and bioactive textiles (Dandin and Kumar, 2007). They are natural polymers which are biodegradables that play diversified roles in bone formation, drug delivery systems, veterinary pharmaceuticals, manufacturing contact lenses, tissue regeneration, treating burn victims and matrix of wound dressing (Ramesh et al., 2005). Used to make medical sutures, silk fibroinbased wound dressing that accelerated wound healing without damaging the newly formed skin (Tasubouchi, 1999a). A blended sericine and fibroin hydrogel has excellent moisture absorbing and desorbing properties and elasticity (Yoshii et al., 2000). After invitro and in-vivo studies using fibroin controlled release tablets, gels and mesosphere, it was reported that sulphated silk fibroins had anti-HIV-1 activity in-vitro, as it interferes with the adsorption of virus particles to CD4+ cells, and completely blocked virus binding to the cells at a concentration of $100 \mathrm{microgm} / \mathrm{ml}$ (Gotoh et al., 2000). The silk fibroin can be used as the substratum for the culture of animal cells in place of collagen (Inouye et al., 1998). Fibroin in aqueous solution is used in preparation of membranes for immobilization of Aspergillus niger glucose-oxidase and Pseudomonas fluorescens lyophilized cells (Demura et al., 1989). $\mathrm{Hu}$, (2006) reported that the Recombinant human-like collagen (RHLC) is blended with fibroin to prepare a novel biocompatible film as a scaffold material for hepatic tissue engineering applications. Silk fibroin membrane acts as a photo sensor for hydrogen peroxide analysis. Silk protein sericin, suppress DMBATPA induced mouse skin tumorigenesis through oxidative stress reduction, inflammatory responses and endogenous tumour promoter TNF-alpha (Zhaorigetu et al., 2003).

\section{CONCLUSION AND FUTURE PROSPECTIVE}

Back in the days Sericulture industry only focused at the utilization of silk fibre for textile industry but recent research and developments in the industry have proved it is a viable multipurpose agro-based industry that has provided various insights in the socio-economic development of different countries through employment opportunities, food security, income generation, women empowerment, tax revenue, environmental safety, agriculture integration and infrastructure development. Research and Development has further extended sericulture applications to new areas of great importance such as human and livestock feeding, cosmetic making, pharmaceutical, biomedical and bioengineering, automobile, house building and art craft. Therefore, Sericulture industry exceedingly qualifies as one of the best agro-based investment due to the multipurpose functions it furnishes mainly the socio-economic development. Attention given to facts stated by different studies of sericulture it's wise to conclude that sericulture can be considered as the most suitable and beneficial agro-based industry for socio-economic present and future development.

\section{RECOMMENDATIONS TO IMPROVE SERICULTURE INDUSTRY:}

- Scientific research and development must be designed to exploit all the areas in the industry that have not been fully utilized like the handling of secondary products of silkworm but this is possible through government support and funding.

- Universities and agriculture institutions should develop curriculum that exhaustively train professionals in sericulture related fields in order to enhance knowledge and skills based training for students at all levels. 
- Strengthening sericulture industry linkages between government and Research institutes, Universities, private company, NGO's and professionals.

- Government should create office of sericulture extension workers at different levels in order to create awareness and extend intended services to farmers through trainings and demonstrations.

- Studying and documenting sericulture practices so as to aid education, dissemination and sensitization of sericulture farmers and out growers and all stakeholders.

- Develop a proper farming system that integrates sericulture activity with other agriculture enterprises namely beef and dairy farming, fish farming, poultry and vegetable production.

- Government to create a reserve fund in form of bank loan/credit for all stakeholders in sericulture industry at a low interest rate in order to facilitate sericulture activities as well as encourage farmers to engage in the industry.

- Infrastructure development like installing silk processing factories in different parts of the country as this will provide employment opportunities to people in the area as well as ready market for the silk products produced farmers.

\section{REFERENCES}

[1] K. Afifa, "Principles of Temperate Sericulture," Kalyani Publications, 2000.

[2] M. F. Baqual, "Problems that hinder the growth of Sericulture in Jammu \& Kashmir State: Workshop on Development of Sericulture in Jammu \& Kashmir State, its future prospects," December 8 to 9, 1995.

[3] M. L. Best, S. G. Maier, "Gender, culture and ICT use in rural South India," Gender Technology and Development, 11: 137-155, 2007.

[4] T. A. Bhat, "An analysis of public private partnership (PPP) in Sericulture in Jammu \& Kashmir," J. of Econ and Sust Devt, 5:11, 2014.

[5] M. A. Bhat, Z. I. Buhroo, A. Aziz, J. Qadir, and M. Azam, "An Overview of Current Scenario of Sericulture Industry in Jammu and Kashmir, India," Int. J. Curr. Microbiol. App. Sci., 9(6): 3813-3824, 2020.

[6] R. Bhatta, K. A. Rao, "Women 's livelihood in fisheries in coastal Karnataka, India," Indian Journal of Gender Studies, 10: 261-278, 2003.

[7] A. S. Bilal, "Structural Changes in Jammu and Kashmir Economy," P.G. Department of Economics, University of Kashmir, 1-94, 2010.

[8] Z. Buhoro, M. Malik, N. Ganai, A. Kamili, B. Bhat, "Comparative performance \& genetic polymorphism in some potential silkworm Bombyx mori L. genotypes," Journal of Cell \& Tissue Research, 16(3):5908- 5915, 2016 b.

[9] S. B. Dandin, S. N. Kumar, "Bio-medical uses of silk and its derivatives," Indian Silk, 45(9): 5-8, 2007.

[10] R. N. Datta, A. Sarkar, S. K. Das, "Glucosamine from Eri silkworms," Indian Silk, 46:22, 2007.

[11] K. A. Lalhmingsangi, "Sustainable Livelihood for Women through Sericulture: A study of IBSDP beneficiaries, Aizawl District, India," International Journal of Humanities and Social Science Invention (IJHSSI), 4: 43-47, 2019

[12] I. Q. S. Farhat, M. A. Malik, S. Awquib, F. A. Malik, "Adoption of Improved Sericulture Practices by Sericulturists in Border Area of Kashmir," International Journal of Agricultural Statistics and Science, 6(1):197-201, 2010.

[13] J. L. Farrar, "Trees of the Northern United States and Canada," Blackwell Publishing, Ames, IA, USA, 1995.

[14] S. Federico, K. L. Maja, G. Isabelle, V. Godelieve, J. V. Erik, D. R. Dirk, and D. Jan, "Tensile strength and host response towards silk and type 1 polypropylene implants used for augmentation of facial repair in a rat model," Gynaecologic and Obstetric, 63(3): 155-62, 2008.

[15] P. Feng, "The study of structure and edibility of silk protein," Food Research Development, 25:51-54, 2004.

[16] D. Gamble, "Silk production by rural women in Dodota Woreda, Ethiopia, Powering Economic Opportunity," 2011.

[17] N. A. Ganie, K. A. Dar, I. L. Khan, R. K. Sharma, and K. A. Sahaf, "Sericulture- A viable option for sustainable livelihood and employment generation for rural population of J \& K," Global Journal of Bioscience and Biotechnology, 1: 200-203, 2018

[18] G. S. Geetha, and R. Indira, "Silkworm rearing by rural women in Karnataka: A path to empowerment," Indian Journal of Gender Studies, 18: 89-102, 2011.

[19] K. Gotoh, H. Izumi, T. Kanamoto, Y. Tamada, H. Nakashima, "Sulfated fibroin, a novel sulfated peptide derived from silk, inhibits human immunodeficiency virus replication in vitro," Bioscience Biotechnology Related Articles, Books Biochemistry, 64:1664-1670, 2000.

[20] Z. Gui, and D. Zhuang, "Study on the silkworm powder and its physiological functions," China Sericulture, 2: 53-54, 2000.

[21] M. L. Gulrajani, "Sericin-a bio-molecule of value," Indian Silk, 45(2): 16-22, 2006.

[22] H. G. Hanumappa, "Economics issues in sericulture: A case study of Karnataka," Sericologia, 25: 209-217, 1993.

[23] S. A. Hashemi, and S. Tabibian, "Application of Mulberry nigra to absorb heavy metal, mercury, from the environment of green space city," Toxicol. Rep., 5: 644-646, 2018.

[24] K. Hu, "Biocompatible Fibroin Blended Films with Recombinant Humanlike Collagen for Hepatic Tissue Engineering," Journal of Bioactive and Compatible Polymers, 21: 23-37, 2006.

[25] K. Inouye, M. Kurokawa, S. Nishikawa, and M. Tsukada, "Use of Bombyx mori silk fibroin as a substratum for cultivation of animal cells," Journal of Biochemical and Biophysical. Methods, 18:159-164, 1998.

[26] M. N. S. Iyengar, "Recycled silk wastes as feed integrated for poultry," Indian Silk, 41(5): 30-31. 2002

[27] Japan Association for International Collaboration of Agriculture and Forestry, (JAICAF), Sericulture in East Africa, (2007). www.jaicaf.or.jp/publications.

[28] F. Kaneez, "Trends in cocoon and silk production in Jammu and Kashmir State-a case of concern," International Journal of Recent Scientific Research, 4(11): 1826- 1830, 2018

[29] K. Y. Kim, P. D. Kang, K. G. Lee, K. Hyung, M. J. Kim, and K. H. Kim, "Microsatellite analysis of the silkworm strains (Bombyx mori): high variability and potential markers for strain identification," Genes \& Genomics, 32:532- 543, 2010.

[30] T. Kiran, Y. Z. Yuan, M. Andrei, Z. Fang, G. Z. Jian, and J. W. Zhao, "1Deoxynojirimycin, its potential for management of non-communicable metabolic disorders" Trends Food. Sci. Technol., 89: 88-99, 2019.

[31] P. R. Koundinya, and K. Thangavaleu, "Silk proteins in Biomedical Research," Indian Silk, 43(11): 5-8, 2005.

[32] P. Kumaresan, and R. G. G. Devi, "An economic analysis of large-scale farming in irrigated sericulture," Annual Report, CTR\&TI, Mysore, 2007.

[33] T. B. Lin, Y. G. Li, and Z. Q. Lv, "Advances in the research and development on the synthesize utilization of mulberry resources," Bull. Seric., 39 (3): 1$4,2008$.

[34] H. C. Mahapatra, "Tropical Tasar biodiversity and forestry: Proceedings of the National workshop on Seri-Biodiversity Conserv, Mar. 7-8. CSGRC, CSB, Hosur, India, 163-167, 2009.

[35] S. K. Majumder, "Scope for new commercial products from sericulture," Indian Silk, 35(12):13-18, 1997.

[36] R. R. Manohar, "Value addition span of silkworm cocoon-time for utility optimization,” International J. Industrial Entomolo., 17(1): 109-113, 2008.

[37] J. Nagaraju, "Silk of India, grace and luster," Biotechnol. News, 3: 4-7, 2008.

[38] C. Prasad, and S. Chandra, "Women in Agriculture. International federation for women in Agriculture," New Delhi, 1991.

[39] S. Qadri, Farhat, and M. A. Malik, "Sericultural Practices by Sericulturists in border area of Kashmir," Int. J. Agricult. Stat. Sci., 6(1):197- 201, 2010.

[40] J. Qian, "The chemical constitution and utilization of silkworm pupae," Science Technology and Food Industry, 5: 42-43, 1997. 
[41] J. Qin, N. He, Y. Wang, and Z. Xiang, "Ecological issues of mulberry and sustainable development," J. Resour. Ecol., 3(4): 330-339, 2012.

[42] Ramakanth and K. V. A. Raman, "Cocoon Palade for better health," Indian Silk, 35(8-9): 35, 1997.

[43] C. S. Ramalaxmi, "Potential for participation of women in Sericulture sector," 2007.

[44] S. Ramesh, C. S. Kumar, S. V. Seshagiri, K. I. Basha, H. Lakshmi, C. G. P. Rao, and Chandrashekaraiah, "Silk filament its pharmaceutical applications," Indian Silk, 44(2): 15-19. 2005.

[45] C. Roy, and K. C. Joshi, "Silkworm pupae as human food," Indian Silk, 34(3): 10, 1995.

[46] C. S. Rui, and L. Mao, "Diels Alder Type Adducts from Morus Cathayana Phyto-chemistry," 57:1231, 2001.

[47] C. Roy, and S. R. Mukherjee, "An analytical study on determinants of income generation in rural sericulture sector of West Bengal," Indian Journal of Economics and Development, 3(2), 168-180, 2015.

[48] R. Bukhari, H. Kour, and A. Aziz, "Women and the Indian Sericulture Industry,” Int. J. Curr. Microbiol. App. Sci., 8(5): 857-871, 2019.

[49] K. S. Ryu, H. S. Lee, and R. W. Choue, "An activity of lowering bloodglucose levels according to preparative condition of silkworm power," Korean Journal of Sericulture Sciences, 39:79-85, 1997.

[50] M. D. Sanchez, "World distribution and utilization of mulberry and its potential for animal feeding. In: Sanchez, M.D. (Ed.). In: In mulberry for Animal Production, FAO, Roma, Italy," Animal Production and Health Paper, Series, 147:1-9, 2002.

[51] F. Sehnal, "Prospects of the practical use of silk sericin," Entomological Res., 38(1): 1-8, 2008

[52] Y. Q. Shi, T. Fukai, H. Sakagami, W. J. Chang, P. Q. Yang, F. P. Wang, and T. Nomura, "Cytotoxic flavonoids with isoprenoid groups from Morus Mongolica," Journal of Natural Products, 64: 181-188, 2001.

[53] K. Shigetaka, and K. Teruo, "Mechanical properties of injection moulded silk fiber/ polypropylene composites," J. the Textile Machinery Society of Japan, 55(8): 82-88, 2002.

[54] H. Singh, and R. H. Andrabi, "Spatial Differentiation in Agricultural Development in Jammu and Kashmir: A Geographical Approach," International Journal of Scientific and Research Publications, 5(8): 1-9, 2015.

[55] K. C. Singh, and N. Suryanarayana, "Eri pupae A popular cuisine too," Indian Silk, 41(12):57-58, 2003.

[56] B. Singh, and H. P. S. Makkar, "The potential of mulberry foliage as feed supplement in India. In: Mulberry for animal production (Ed. M. D. Sanchez)," Animal Health and Production Paper, FAO, Rome, Italy, 147: 139-153, 2000.

[57] K. P. Singh, "Medicinal properties of mulberry: a review," Indian Drugs, 34:488-492, 1997.

[58] B. K. Singhal, A. Dhar, M. A. Khan, B. B. Bindroo, and R. K. Fotedar, "Potential economic additions by mulberry fruits in sericulture industry," Plant Horticulture Technology, 9: 47-51, 2009a.

[59] B. K. Singhal, M. A. Khan, A. Dhar, and B. B. Bindroo, "New vistas for industrial exploitation of mulberry fruits in horticulture industry," International Conference on Horticulture (ICH2009), PNASF, VEGINET, UAS, Bangalore, India, 1:4-O6, 2009b.

[60] N. Suryanarayana, and A. K. Shrivastava, "Monograph on Tropical Tasar Silkworm," Central Tasar Research and Training Institute, Central Silk Board, Ranchi, India, 1-87, 2005.

[61] K. Thangavelu, "Future research strategy for non-mulberry sericulture with particular reference to Tasarculture: Advances in Indian sericulture research. Proceedings of the National Conference on Strategies for Sericulture
Research and Development," Nov. 16-18, CSRTI, CSB, Mysore, India, 365$368,2002$.

[62] R. B. Thapa, and K. B. Shrestha, "Silkworm rearing technology," Proceedings of the Workshop at Bhaktapur, Nepal, Dec. 21, 1999.

[63] R. O. Trigueros, and P. Villalta, "Evaluación Del Uso de Follaje Deshidratado de Morera (Morus alba) en Alimentación de Cerdos de la Raza Landrace en Etapa de Engorde. En: Resultados de Investigación," CENTA, El Salvador, 150-155, 1997.

[64] K. Tsubouchi, "Occlusive dressing consisting essentially of silk fibroin and silk sericin and its production," Japan Patent 11-070160A, 1999b.

[65] K. Velayudhan, N. Balachandran, R. K. Sinha, and C. K. Kamble, "Utility of silkworm pupae: A new dimension as food and medicine," Indian Silk, 47(1): 11-18, 2008.

[66] K. R. Venkatesh, and S. Chauhan, "Mulberry: Life enhancer," Journal of Medicinal Plant Research, 2: 271-278, 2008

[67] K. R. Venkatesh, C. Gautam, N. Shobha, and R. L. Shankar, "Use of mulberry leaves as supplementary food in cow and goat to improve milk production," Int. J. Appl. Res., 1(13): 81-84, 2015

[68] Y. Wang, D. J. Blasioli, H. J. Kim, H. S. Kim, and D. L. Kaplan, "Cartilage tissue engineering with silk scaffolds and human articular chondrocytes," Biomaterials, 27(25): 4434-4442, 2003.

[69] Y. Wang, L. Xiang, C. Wang, C. Tang, and X. He, "Antidiabetic and antioxidant effects and phytochemicals of mulberry fruit (Morus alba L.) polyphenol enhanced extract," PLoS ONE, 8 (7): e71144, 2013.

[70] X. Yan, Y. Zhao, W. Wang, X. Gu, and Y. Yang, "Biological safety assessment of the silk fibroin-based interplay of nerve guidance conduits in vitro and in vivo," Advanced Studies in Biology, 1(3): 119-138, 2009.

[71] X. Yang, L. Yang, and H. Zheng, "Hypolipidemic and antioxidant effects of mulberry (Morus alba L.) fruit in hyperlipidaemia rats," Food Chem. Toxicol., 48: 2374-2379, 2010a.

[72] G. Zhang, J. Yang, X. Zhao, K. Feng, and X. Gao, "Study on the root system distribution mulberry and its characteristics of soil and water conservation," Sci. Seric., 23:59-60, 1997.

[73] H. Zhang, Z. F. Ma, X. Luo, and X. Li, "Effects of mulberry fruit (Morus alba L.) consumption on health outcomes: a mini-review." Antioxid. Basel Switz., 7 (5): 69, 2018.

[74] S. N. Zhaorigetu, M. Sasakim, H. Watanbe, and N. Kato, "Silk protein, sericin, suppresses DMBA-TPA induced mouse skin tumorigenesis by reducing oxidative stress, inflammatory responses and endogenous tumor promoter TNF-alpha," Oncology Reports, 10: 537-543, 2003.

[75] R. Zulkifli, K. S. Peiand, and C. H. Azhari, "Interlaminar fracture properties of multi-layer woven silk fibre / polyeste composites," Asian J. Applied Sci., 1(2): 177-184, 2008.

\section{AUTHORS}

First Author - Brian Ssemugenze, Tropical Institute of Development Innovations, P.O. Box, 397, Mukono-Uganda, bryanssemugenze@gmail.com

Second Author - Joseph Esimu, Tropical Institute of Development Innovations, P.O. Box, 397, Mukono -Uganda

Third Author - Janet Nagasha, Tropical Institute of Development Innovations, P.O. Box, 397, Mukono -Uganda Fourth Author - Clet Wandui Masiga, Tropical Institute of Development Innovations, P.O. Box, 397, Mukono-Uganda, wmasiga@hotmail.com 